\title{
Performance Evaluation of Tractor Drawn Turmeric Digger
}

\author{
Deshvena Shailaja $^{1 *}$, R.T. Ramteke ${ }^{1}$ and S.N. Solanki ${ }^{2}$ \\ ${ }^{1}$ Department of EOES, Department of Farm Machinery \& Power Engineering, ${ }^{2}$ Department of \\ FMPE, Department of Farm Machinery \& Power Engineering, College of Agricultural \\ Engineering, Parbhani, V.N.M.K.V. Parbhani, Maharashtra State, India \\ *Corresponding author
}

\begin{abstract}
Keywords
Turmeric digger, Design parameters, Rake angle, Soil separation, Power requirement

Article Info

Accepted:

17 March 2019

Available Online:

10 April 2019 Strips shape, Inverted ' $\mathrm{V}$ ' shape and Crescent shape for digger machine for comparing on field test. The design parameters - soil moisture content, rake angle of digging unit and speed of operation of digger machine were evaluated. Performance parameters like digging efficiency, damaged percentage of turmeric rhizomes, soil separation index and power requirement were measured at different levels of design parameters and design values of different components were determined. In strips shape digging blade the maximum digging efficiency was observed 97.35 per cent at $3.0 \mathrm{~km} / \mathrm{h}$ speed of operation with $20^{\circ}$ of rake angle and optimum soil moisture content was $14.23 \pm 0.35$ respectively. Minimum damage percentage of turmeric rhizomes of 4.7 per cent was observed in strips shape digging blade with $20^{\circ}$ rake angle at $3.0 \mathrm{~km} / \mathrm{h}$ speed of operation and soil moisture content $14.23 \pm 0.35$ per cent respectively. The soil separation index was most affected by rake angle of soil digging unit and speed of operation of digger machine. A minimum soil separation index of 0.25 was obtained at $15^{\circ}$ and $20^{\circ}$ rake angle at $3 \mathrm{~km} / \mathrm{h}$ speed of operation digger machine respectively. An average minimum power requirement for the operation of turmeric digger for selected three digging blades i.e. strips shape, inverted ' $v$ ' shape and crescent shape at a speed of $1.5 \mathrm{~km} \cdot \mathrm{h}^{-1}$ was $0.91,1.15$ and $1.21 \mathrm{~kW}$ at $15^{\circ}$ of rake angle and soil moisture content $14.23 \pm 0.35$ per cent.
\end{abstract}

\section{A B S T R A C T}

Performance evaluation of tractor drawn turmeric digger was studied by conducting experiments on a test set-up having provision to vary design variables. The test set-up consists of digging unit and soil separation unit. Three digging blades are selected i.e.

\section{Introduction}

Turmeric is essentially a tropical crop and India is its largest producer, consumer and exporter in the world. India accounts for about 80 per cent of total world output of turmeric, though major part of its produce is being utilized within the country (Singh
2004). Turmeric occupies about 6 per cent of the total area under spices and condiments in India (Moghe et al., 2012).

Turmeric is grown in as many as 25 states of India with Andhra Pradesh, Tamil Nadu, Maharashtra, Karnataka and Odisha being the leading producers. Other main producers of 
turmeric are Gujarat, West Bengal, Assam and Meghalaya. India has nearly 199 thousand hectares under turmeric cultivation with a total production of 1062 thousand tonnes during (Anonymous 2012a). Andhra Pradesh topped both in area and production during 2011-12.

Kadte (2017) studied on economics of turmeric production in Maharashtra and concluded that Turmeric production in India has shown a fluctuating trend in last five years.

It was 43000 tones in 2011-12, and increased to 65000 tones in 2012-13. Again decreased to 37000 tones in 2013-14 and then increased to 70000 tones in 2014-15. The annual turmeric production was 48500 tones in 201516. Hence price of turmeric is not fixed and tend to fluctuate year by year.

Maharashtra state in India ranks sixth in area under turmeric cultivation. The area under crop was 11000 hectare with a production of 45000 tones and productivity of 4.09 tonnes/ hectare during 2015-16. In Maharashtra Sangali, Satara, Hingoli, Nanded, Parbhani are the major turmeric growing districts. It is one of the major crops in Sangali district. In Sangali the area under turmeric is 1500 hectares, whereas production and productivity is 13000 tonnes and 8.6 tonnes/ hectare, respectively in 2015-16.

By adopting mechanical harvesting manpower requirement was found $60 \%$ lower as compared to manual digging, whereas crop damage was less than 2\% (Sukhwinder et al., 2007). So there is a need for mechanization in root crop harvesting to reduce human drudgery and to reduce the cost of cultivation by $30-50 \%$ with better harvesting efficiency compared to manual harvesting (Vatsa et al., 1996). Hence, successful harvest mechanization requires.
The design parameters of any root or tuber crop harvester effects the performance of the machine. Generally the root harvester consists of digging blade and a soil separator. The tool geometry of the blade effects the digging efficiency of the harvester and draft required. The tool geometry governs by rake angle of the blade and friction angle of the soil (Agbetoye et al., 1998). The draft increases with width, depth and rake angle of the tool. The cross-sectional area of the soil disturbed did not change appreciably with rake angle, but significant increase in draft with angle resulted in markedly diminished soil cutting efficiency (Saleh A. Al- Suhaibani, Abdurrahman Al - Janobi (1997). The convex type blades with $20^{\circ}$ rake angle performed better than the concave with the total recovery of 87.6 to $93.44 \%$ while it was only 77.47 to $82.14 \%$ for concave type blade and the depth of operation of potato digger should be 200 $\mathrm{mm}$ in order to avoid damage and loss of potatoes (Trivedi and Singh, 1975).

Mechanical diggers were developed for underground crops like potato, onion, groundnut and cassava but there is least information is available on turmeric digging with mechanical means of design and operational parameters and power consumption. The objective of this paper is to determine design values of turmeric digger machine by conducting experiments made for this purpose.

\section{Materials and Methods}

The basic function required for turmeric digger is to dig and lift the turmeric rhizomes and soil mass; separate soil mass from rhizomes clumps, leaving them over soil surface for collection with minimum damage. There are two basic components in turmeric digger, digging blade and soil separation unit. The different variables which affect the turmeric digger were soil moisture content, 
rake angle, and operating speed of digger machine.

The digger was designed for digging turmeric rhizomes by lifting the soil and rhizomes without tops from the field with the help of digging unit and subsequently transferring the same onto a separating unit where turmeric rhizomes are separated from the soil through soil separator.

Functional requirements were set for the design of Digger: a) The Digger should dig rhizomes planted on flat bed of total row width of $120 \mathrm{~cm}$, leaving two rows simultaneously in a single operation. b) The Digger should dig the turmeric rhizomes from soil in such a way that a minimum amount of soil should be lifted with the plant root mass. c) The Digger should leave turmeric rhizomes open on the soil surface at the rear of the tractor- digger system, which could be picked up manually with minimum efforts and in minimum time. d) Damage to turmeric rhizomes during harvesting operation i.e. cut, crush and bruise should be as low as possible. e) It should be operated by tractors of 35 to 45 hp range, being the common size of tractor available on Indian farm. f) The Digger should be simple in design and construction, and efficient in its performance.

The experiments were conducted on experimental farm where the turmeric plants are grown at Khanapur phata village near to Parbhani district. Before conducting the experiments the haulms or tops of the turmeric plants are destroyed 2-3days before harvesting by mechanical means. The experimental setup with above components was used to determine the optimum machine parameters for better performance of the digger machine at optimized moisture content test was conducted by varying different machine parameters like moisture content, rake angle, operating speed of digger machine at different levels and replicated thrice. The observations were recorded for number of turmeric rhizomes harvested, number of turmeric rhizomes damaged, weight of soil collected with turmeric rhizomes and power requirement.

The data on performance parameters were analyzed using factorial randomized block design and statistical parameters were evaluated using Design Experts and MAU STAT software (Table 1 and 2).

i) Strips shape blade.

ii) Inverted 'V' shape blade.

iii) Crescent shape blade.

\section{Results and Discussion}

The performance parameters of the test set up of turmeric digger was evaluated for three different soil moisture content i.e. $(12.23 \pm 0.18 \%), \quad(14.23 \pm 0.35 \%) \quad$ and $(16.28 \pm 0.38 \%)$ for three different rake angles of $15^{\circ}, 20^{\circ}$ and $25^{\circ}$; at three different operating speeds of digger machine $1.5 \mathrm{~km} / \mathrm{h}$, $3.0 \mathrm{~km} / \mathrm{h}$ and $4.5 \mathrm{~km} / \mathrm{h}$ for three different shapes of digging blades. Performance parameters i.e. Digging efficiency \%, Damage Percentage \%, Soil separation Index and Power Requirement $\mathrm{kW}$, these design value are evaluated by field observations were showed in graphical representation form to the requirement (Fig. 1-16; Plate 1 and 2).

\section{Percentage of digging of turmeric rhizomes}

Above graph shows the comparative study digging or harvesting percentage of three different shapes of blades in this graph values are influenced by soil moisture content, rake angle and speed of operation of digger machine. The digging percentage increased at middle point of rake angle and later decreased marginally. The maximum harvesting percentage observed in Strips shape, Inverted 
'v' shape and Crescent shape respectively were $97.35 \%$; $94.86 \%$ and $89.95 \%$ was obtained respectively

\section{Comparative analysis of digging efficiency $\%$ for three different shapes of blade}

In this graphical representation the maximum digging efficiency observed with respect to all combination of variables i.e. soil moisture content, rake angle and speed of operation for three different shape blade where comparative analysis was made, the maximum digging efficiency observed in Strips shape digging blade $97.35 \%$ later on Inverted 'v' shape digging blade obtain digging efficiency 94.86 $\%$ which was more than Crescent shape digging blade digging efficiency.

Crescent shape digging blade obtain low digging efficiency $89.95 \%$ due to the wide curve shape of blade which made maximum damage to turmeric rhizomes on two row turmeric flat bed.

In case of turmeric harvesting percentage, at $14.23 \pm 0.35$ per cent maximum harvest of 97.35 per cent was obtained for strips shape of digging blade and all combination of machine variables. This was because at $14.23 \pm 0.35$ per cent moisture, soil was in friable and crumby, and suitable of better operation of any soil working tool. At this stage, the required depth of operation was achieved, so there will be better digging and harvesting per cent might have increased.

At $12.23 \pm 0.18$ per cent soil moisture, the average turmeric harvesting percentage of 90.20 was achieved which was lower than turmeric harvested at $14.23 \pm 0.35$ per cent soil moisture content. There is a reduction in the turmeric harvesting percentage in inverted ' $\mathrm{v}$ ' shape and crescent shape of digging blade because soil penetration stress achieved at one point in both inverted ' $v$ ' and crescent shape of digging blade but in strips shape of digging blade uniform soil penetration stress achieved at working width of digging blade.

\section{Percentage of turmeric rhizomes damaged}

For better performance of any root crop harvesting machine damage percent should be less. The influence of moisture soil content, rake angle and speed of operation affects on percentage of turmeric rhizomes damaged indicated that lower damage percentage was observed in Strips shape digging blade compare to two different shape blades damage percentage obtained.

The result shows that different level of machine design parameter on Turmeric damage percentage as shown in graph.

In this graphical representation indicate that lower damage percentage observed in strips shape digging blade with $20^{\circ}$ rake angle and average damage percentage was $4.7 \%$ at 3.0 $\mathrm{km} / \mathrm{h}$ speed of operation and soil moisture content $14.23 \pm 0.35 \%$.

The damage percentage increased with increase in speed of operation and if soil moisture content is not optimum then also damage percentage increased. The rake angle of digging unit only initial stage maximum damage occurred due to the desired depth was not obtained at $15^{\circ}$ rake angle and the rake angle at $25^{\circ}$ damage was not occurred but the draft requirement was maximum which was not economical in performance.

There is no much difference in the turmeric rhizome damage percentage between $20^{\circ}$ and $25^{\circ}$ of rake angle. In crescent shape digging blade due to the wide curve shape of blade which made maximum damage to turmeric rhizomes. In Inverted ' $v$ ' shape digging blade rhizomes damage occurred due to its down ward $\mathrm{V}$ shape which was not lift desired 
turmeric bed of two row turmeric crop planted on bed while lifting rhizomes.

In strips shape lower damage occurred due to uniform soil penetration stress achieved at working width of digging blade.

\section{Soil separation index}

After digging of turmeric rhizomes the soil was separated from turmeric rhizomes with the help of soil separating unit. To measure the efficiency of the turmeric digger in this regard, soil separation index was defined. For better separation of soil from turmeric rhizomes the value of soil separation index should be minimum. Soil separation index is a function of moisture content and travel time of soil over soil separator. Travel time of soil is further depends upon speed of operation and rake angle of digging unit.

The soil separation index initially decreased later on remained almost same up to $20^{\circ}$ rake angle afterwards increase in rake angle soil separation index also increased. The average minimum soil separation index of 0.25 was obtained at $15^{\circ}$ and $20^{\circ}$ rake angle the average soil separation index were very closely distributed for two levels of rake angle at 3 $\mathrm{km} / \mathrm{h}$ speed of operation digger machine. The average maximum soil separation index of 0.53 was obtained at $20^{\circ}$ rake angle at $4.5^{\circ}$ rake angle.

Comparing three digging blades Strips shape digging blade indicate the minimum soil separation index due to each strip of blade soil falls down.

\section{Power requirement}

Power is the main factor for any digging operation. Power requirement will depend upon the soil metal friction, tool geometry and depth of operation. The most important factor for deciding cost economics is power requirement. Power requirement was determined from draft measured by using dynamometer during actual field experiments. The power requirement had direct relation with moisture content, rake angle and speed of operation. The pattern of power requirement for harvesting operation at different combinations of soil- machine parameters as fallows.

The power requirement increased with increase in rake angle and very small change with increase in length and angle of soil separator. The average minimum power requirement at $15^{\circ}$ rake angle was $0.96 \mathrm{~kW}$ obtained with $3.0 \mathrm{~km} / \mathrm{h}$ speed of operation for Strips shape digging blade and the maximum power requirement at $25^{\circ}$ rake angle with 4.5 $\mathrm{km} / \mathrm{h}$ speed of operation of digger machine.

Comparing three digging blades Strips shape digging blade indicate the minimum power requirement due to easily movement of digging blade gap between each strip of blade soil falls down and naturally it required low power requirement. The wide working width of cut of digging blade was made draft distribution equally trough out blade so power will minimize, remaining digging blades which made maximum power requirement at one point on blade.

\section{Influence of soil moisture content on overall performance parameter}

At lower soil moisture clod formation was a problem. These clods were difficult to separate from turmeric, as these clods were larger than turmeric diameter and hard to break and did not pass through soil separator web as spacing in soil separator's web was based on biometric properties of turmeric. Similarly, at higher soil moisture i.e.at $16.28 \pm 0.38$ per cent, there was reduction in the harvesting percentage mainly due to less 
soil separation and at this moisture the depth of operation could be more than optimum depth which caused excessive soil-mass with harvested turmeric and affected soil separation. When damage to turmeric was considered, it decreased as soil moisture increased.
Influence of rake angle on overall performance parameter

When rake angle was considered, it mainly affect percentage of turmeric harvested, percentage of turmeric damaged and power requirement. It did not influence soil separation significantly.

Table.1 Plan of experiments on test setup for three different shape of digging blade

\begin{tabular}{|c|c|c|}
\hline Variables & Levels & $\begin{array}{c}\text { Performance } \\
\text { parameters }\end{array}$ \\
\hline $\begin{array}{c}\text { Soil } \\
\text { Moisture } \\
\text { Content } \\
(\%)\end{array}$ & $\begin{array}{c}\mathrm{M}_{1}= \\
16.28 \pm 0.38 \\
\mathrm{M}_{2}= \\
14.23 \pm 0.35 \\
\mathrm{M}_{3}= \\
12.23 \pm 0.18\end{array}$ & $\begin{array}{c}\text { Digging } \\
\text { efficiency \% } \\
\text { Damage } \\
\text { Percentage \% } \\
\text { Soil separation } \\
\text { Index }\end{array}$ \\
\hline $\begin{array}{c}\text { Rake } \\
\text { Angle } \\
\text { (Degree) }\end{array}$ & $\begin{array}{l}\mathrm{R}_{1}=15 \\
\mathrm{R}_{2}=20 \\
\mathrm{R}_{3}=25\end{array}$ & $\begin{array}{c}\text { Power } \\
\text { Requirement } k W\end{array}$ \\
\hline $\begin{array}{c}\text { Operating } \\
\text { Speed } \\
(\mathrm{Km} / \mathrm{h})\end{array}$ & $\begin{array}{l}\mathrm{S}_{1}=1.5 \\
\mathrm{~S}_{2}=3.0 \\
\mathrm{~S}_{3}=4.5\end{array}$ & \\
\hline
\end{tabular}

Table.2

\begin{tabular}{|c|l|}
\hline Sr. no. & \multicolumn{1}{|c|}{ Particulars } \\
\hline $\mathbf{1}$ & Three point linkage \\
\hline $\mathbf{2}$ & Main frame \\
\hline $\mathbf{3}$ & Gear Box \\
\hline $\mathbf{4}$ & Digging blade \\
\hline $\mathbf{5}$ & Conveyor bars \\
\hline $\mathbf{6}$ & Power transmission system \\
\hline $\mathbf{7}$ & Transport wheel \\
\hline $\mathbf{8}$ & Gauge wheel \\
\hline $\mathbf{9}$ & Canvas belt \\
\hline $\mathbf{1 0}$ & Star wheel \\
\hline $\mathbf{1 1}$ & Reduction pulley \\
\hline $\mathbf{1 2}$ & Input shaft \\
\hline $\mathbf{1 3}$ & Output shaft \\
\hline
\end{tabular}


Fig.1 Graphical representation of digging efficiency of strips shape blade

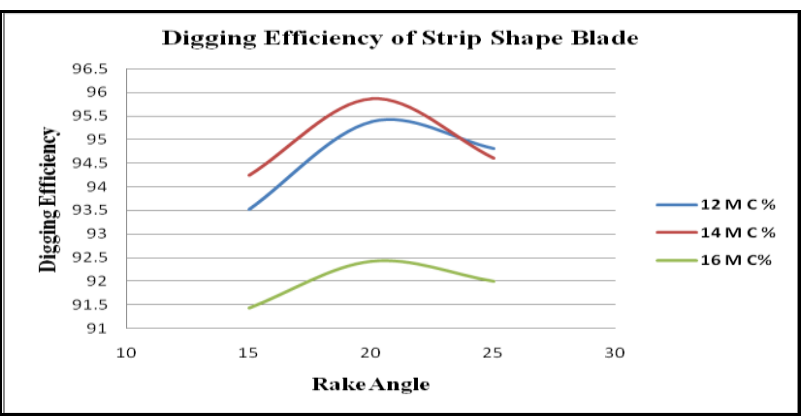

Fig.2 Graphical representation of digging efficiency of inverted 'v' shape blade

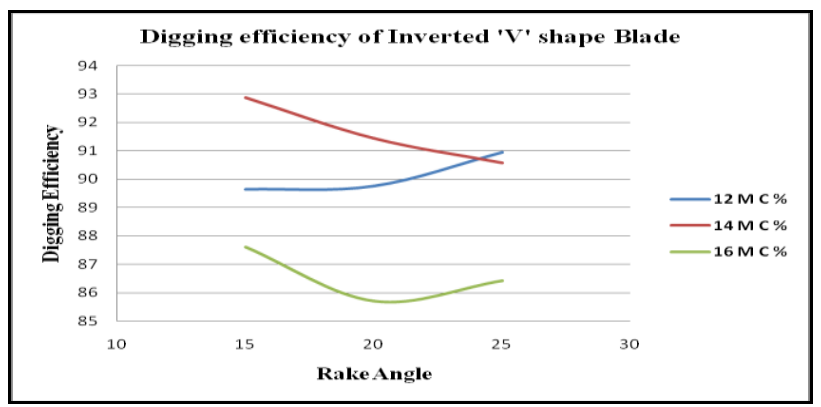

Fig.3 Graphical representation of digging efficiency of crescent shape blade

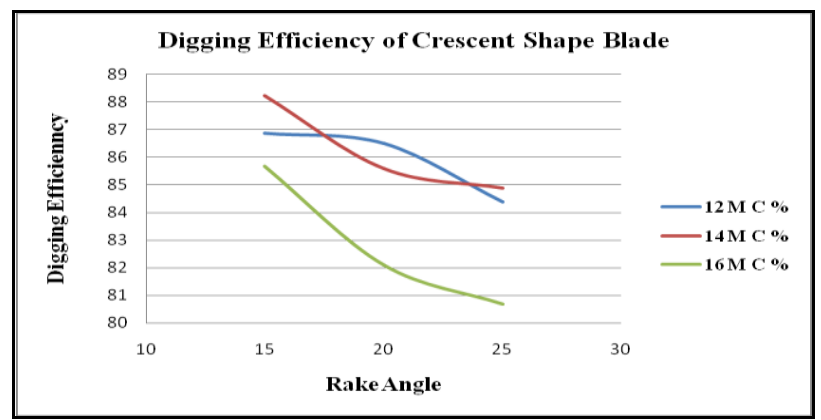

Fig.4 Comparative analysis of digging efficiency for three different shape of digging blade

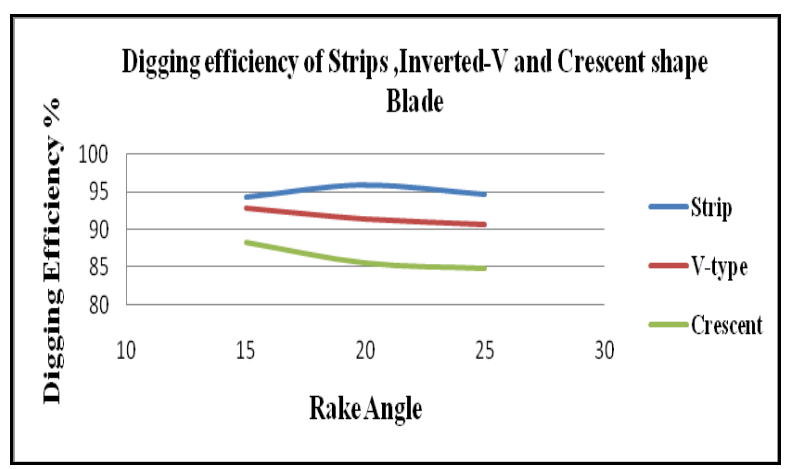


Fig.5 Graphical representation of damage percentage of strips shape blade

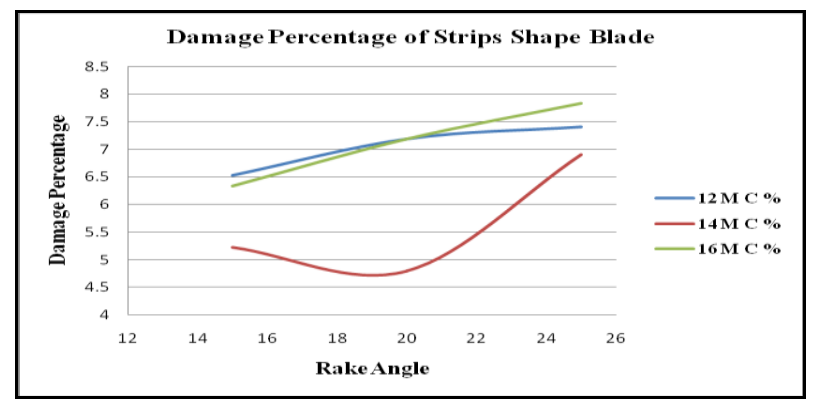

Fig.6 Graphical representation of damage percentage of inverted 'v' shape blade

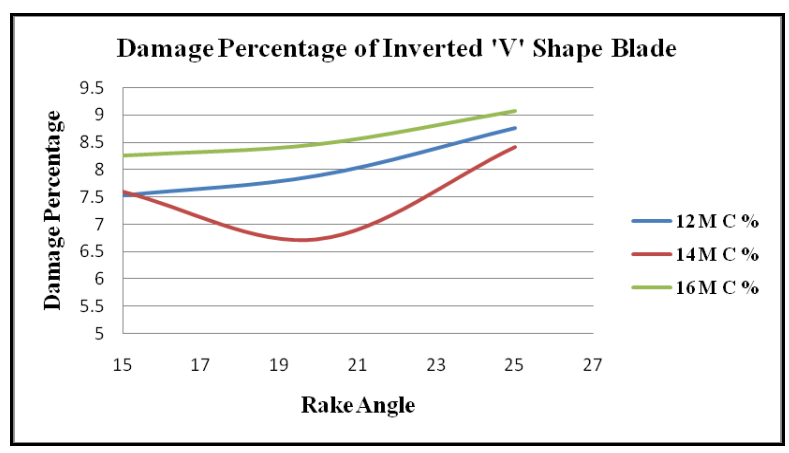

Fig.7 Graphical representation of damage percentage of crescent shape blade

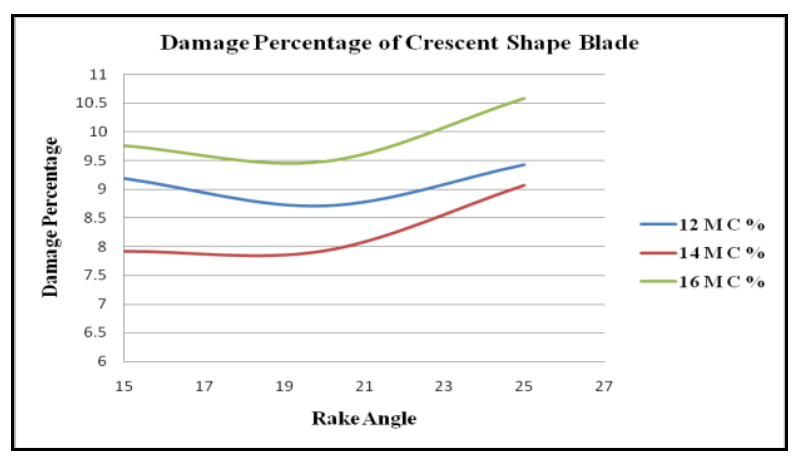

Fig.8 Comparative graph of damage percentage for three different shape of digging blade

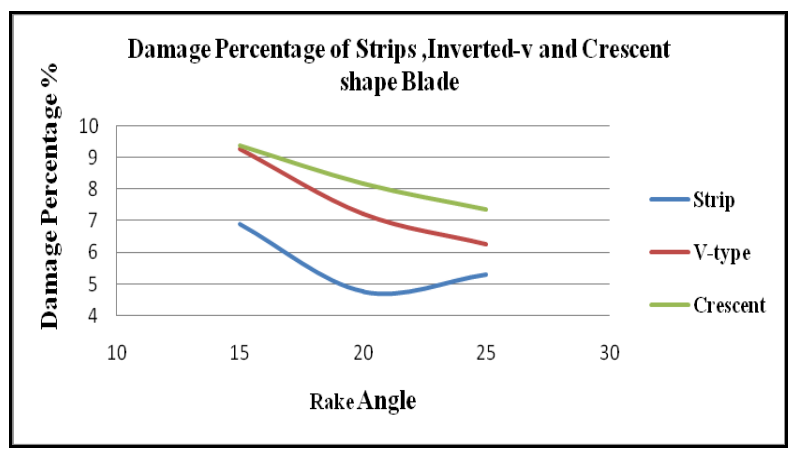


Fig.9 Graphical representation of soil separation index of strips shape blade

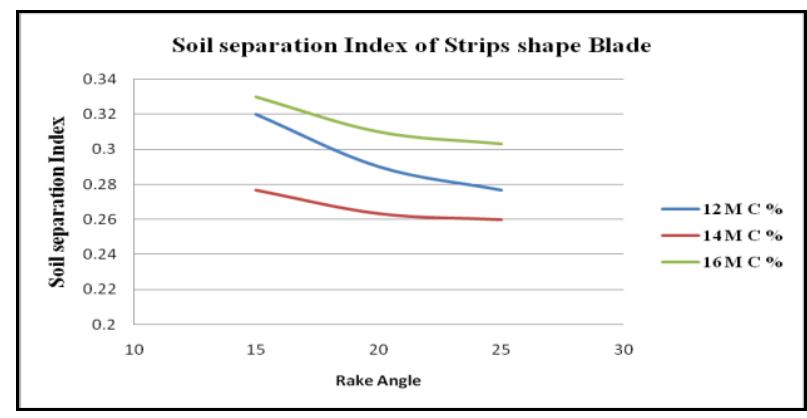

Fig.10 Graphical representation of soil separation index of inverted 'v' shape blade

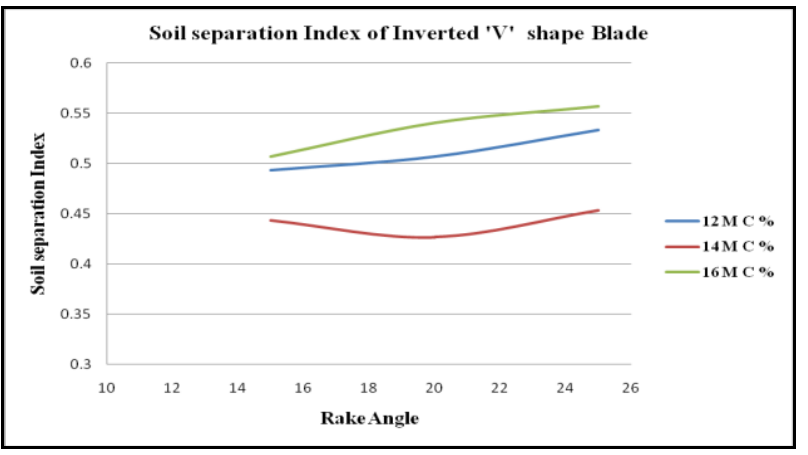

Fig.11 Graphical representation of soil separation of crescent shape blade

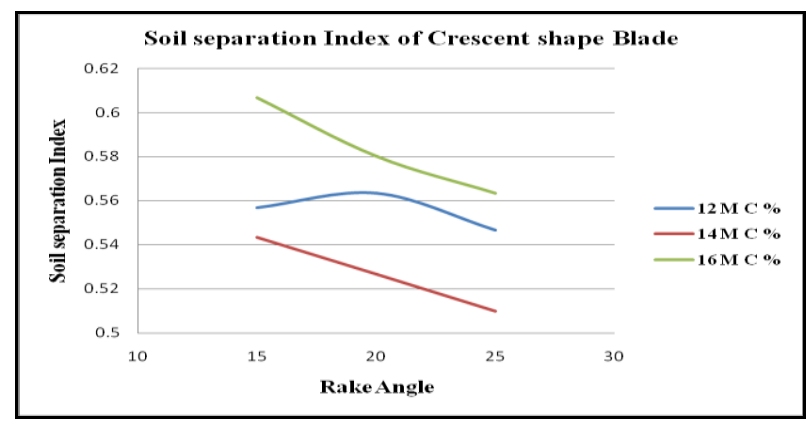

Fig.12 Comparative analysis of soil separation index for three different shape of digging blade

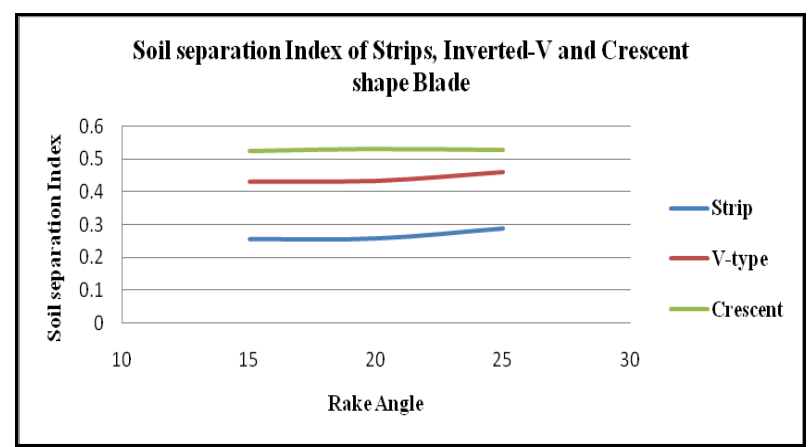


Fig.13 Graphical representation of power requirement of strips shape blade

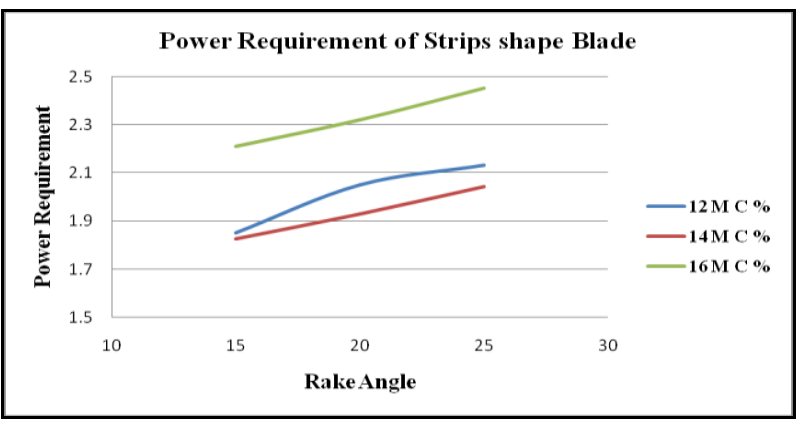

Fig.14 Graphical representation of power requirement of inverted 'v' shape blade

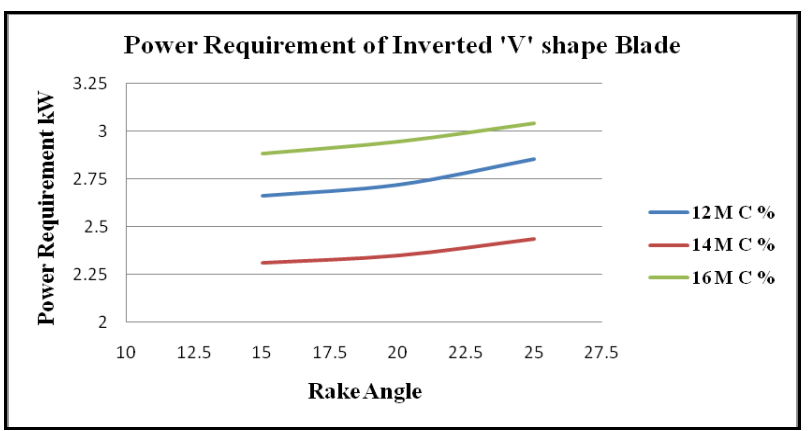

Fig.15 Graphical representation of power requirement crescent shape blade

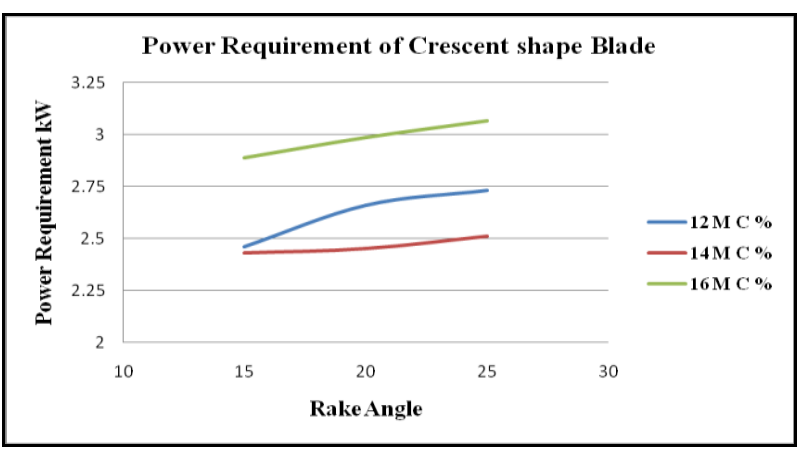

Fig.16 Comparative analysis of power requirement for three different shapes of digging blade

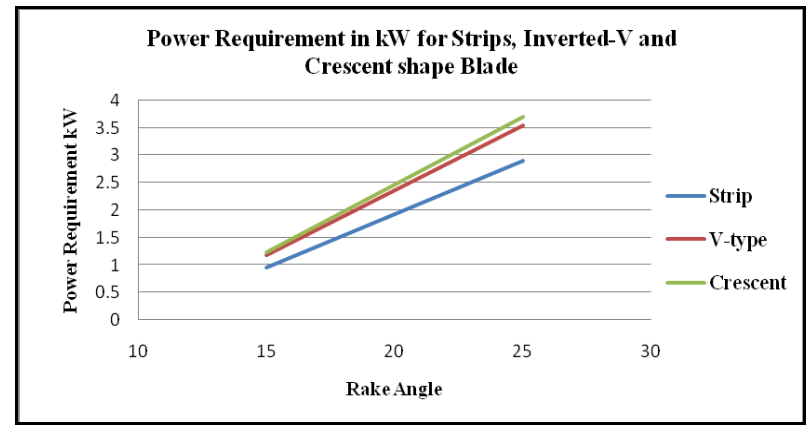




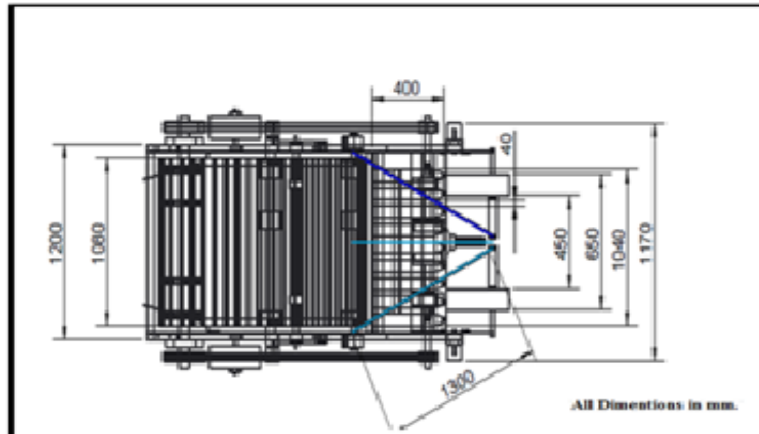

Fig.1 Top view of turmeric digger machine.

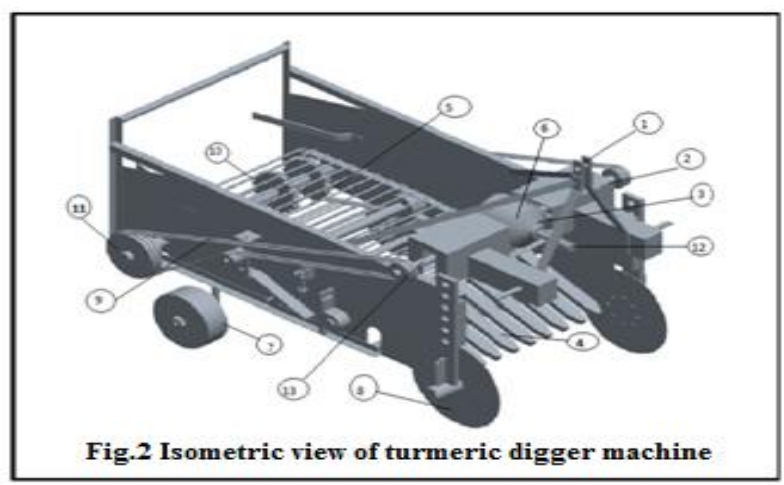

Plate.1 Different shape of blades

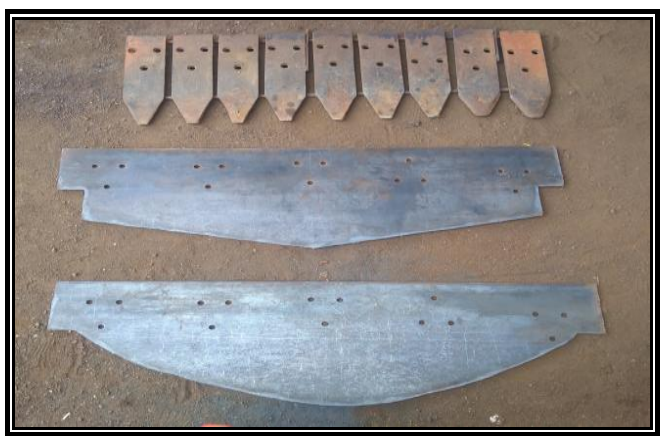

Plate.2 Field performance of Turmeric digger

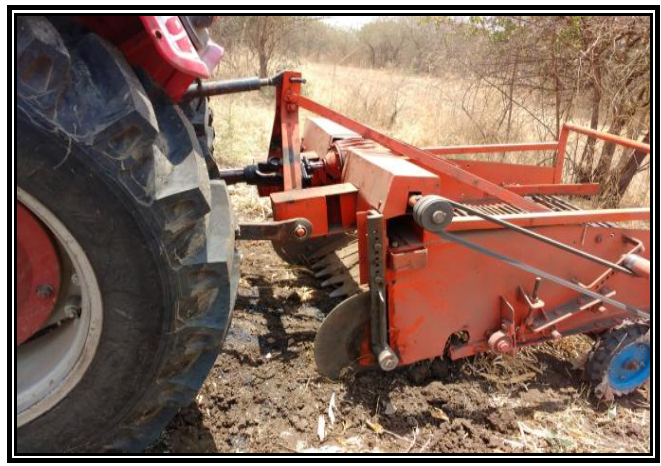




\section{Influence of speed of operation of digger machine on overall performance parameter}

As soil separation was a function travel time on soil separator, soil separation index decreased as speed of operation increased. At a speed of operation of $1.5,3.0$ and $4.5 \mathrm{~km} / \mathrm{h}$ the soil separation indices were $0.45,0.44$ and 0.46. This suggested that soil separation increased as speed of operation decreased up to $3.0 \mathrm{~km} / \mathrm{h}$ and with further increase in the speed of operation, the soil separation index remained constant. When the speed ratio is less the material (Soil+ rhizomes) transferred to the conveyor is too much to be handled by the elevator as the speed of elevator is less.

Conclusions of the study are as follows:

- The tractor drawn turmeric digger with strips shape of digging blade gave an average maximum percentage of turmeric digging of $97.35 \%$ at 3.0 $\mathrm{km} / \mathrm{h}$ speed of operation with $20^{\circ}$ of rake angle and optimum soil moisture content was $14.23 \pm 0.35$, respectively.

- The average minimum percentage of turmeric rhizome damage $4.7 \%$ was observed in strips shape digging blade with $20^{\circ}$ rake angle at $3.0 \mathrm{~km} / \mathrm{h}$ speed of operation and soil moisture content $14.23 \pm 0.35 \%$, respectively.

- $\quad$ The average minimum soil separation index 0.25 was obtained at $15^{\circ}$ and $20^{\circ}$ rake angle the average soil separation index were very closely distributed for two levels of $15^{\circ}$ and $20^{\circ}$ rake angles at $3.0 \mathrm{~km} / \mathrm{h}$ speed of operation digger machine.

- Power requirement is very less for strips shape digging blade and much effected by Crescent shape digging blade. An average minimum power requirement was $0.96 \mathrm{~kW}$ at $15^{\circ}$ rake angle with $1.5 \mathrm{~km} / \mathrm{h}$ speed of operation for Strips shape digging blade. As the rake angle increases, power requirement increased.

- $\quad$ Overall, Strips shape of digging blade selected for turmeric digger machine with $20^{\circ}$ rake angle at $3.0 \mathrm{~km} / \mathrm{h}$ speed of operation was considered for efficient turmeric digging at $14.23 \pm 0.35$ optimum moisture content.

\section{References}

Agbetoye, L.A.S., Kilgour, J., Dyson, J. 1998. Performance evaluation of three prelift soil loosening devices for cassava root harvesting. Soil \& Tillage Research. 48: 297-302.

Ahaneku, I.E., Ani, A.O., Orwualu, A.P. 2008. Effect of soil moisture and tool speed on draught and power requirement of disc plough. Nigerian Journal of Technology. 1-9.

Anonymous (2012a) Area, production and yield of turmeric in India. http://www.indianspices.com

Chatterjee, S.S., Seshadri, V.S., Swaroop, V. 1995. Improving the productivity in vegetables crops - Challenge of the decade (In) sustaining crop and animal productivity. The Challenge of the Decade. Ed. D. L. Dev, Associated.. Ed. D. L. Dev, Associated Publishing Company, New Delhi. Pp. 231-246.

Feller, R., Mizrach, A., Zaltzman, A., Schmilovitch, Z. 1984. Gravity separation over a mesh belt conveyor. Journal of Agricultural Engineering Research. 26:371-377.

Hagen, K.B., Jostein, H., Ringdahl, K.H. 1993. Physiological and subjective responses to maximal repetitive lifting employing stoop and squat technique. European Journal of Applied Physiology and Occupational Physiology. 67(4): 291-297 
Kadte. A. J , D.S. Perke and P. S. Kale (2018) Economics of Turmeric Production in Sangli District of Maharashtra, India. Int.J. Curr. Microbial. App. Sci. (2018) Special Issue-6: 2279-2284.

Kalloo, G. 1998. Proceedings of the National consultation on Horticultural Research, Development and Export: 84-89. Project Directorate of Vegetable Research, Varnasi.

Moghe S M, Zakiuddin K S and Arajpure V G (2012) Design and development of turmeric polishing machine. Int $\mathbf{J}$ Modern Engi Res 2: 4710-13.

Saleh A. Al- Suhaibani, Abdulrahman Al Janobi. 1997. Draught requirement of tillage implements operating on sandy-loam soil. Journal of Agricultural Engineering Research. 66(177-182).

Singh, P., Pandey, K. P. 1981. Soil separation and power requirement of a potato elevator digger. Agricultural Mechanization in Asia, Africa and Latin America. 12(3): 27-29 Journal of the Indian Potato Association. 34
(3-4).

Singh. S (2004) Crisis and diversification in Punjab agriculture: Role of state and agribusiness. Econ Polit Weekly, 39: 5583-90.

Srivastava, A.P., Samuel, D.V.K., Indra, Mani. 2009. Mechanization of vegetable production and post harvest management. First edition, Westville Publishing House, New Delhi.

Sukhwinder, S., Sanjay. R., Manjit, S. 2007. Design and development of offset type digger for sugarcane + potato intercropping.

Trivedi, S.K., Singh, R.K. 1975. Design and development of two row tractor drawn potato digger. Unpublished B.Tech. Thesis in Agricultural Engineering Department. G.B. Pant University of Agricultural and Technology, Pantnagar, Nainital.

Vatsa, D.K., Singh, S.P., Verma, M.K. 1996. Comparative studies on performance of power tiller operated potato diggers in hills. Journal of the Indian Potato Association. 23(3/4):121-129.

\section{How to cite this article:}

Deshvena Shailaja, R.T. Ramteke and Solanki, S.N. 2019. Performance Evaluation of Tractor Drawn Turmeric Digger. Int.J.Curr.Microbiol.App.Sci. 8(04): 2198-2210. doi: https://doi.org/10.20546/ijcmas.2019.804.258 